\title{
The Effect of Classroom Management on Student Learning Motivation in Social Science Subject in Fourth Grade of Telkom Elementary School of Rappocini District of Makassar.
}

\author{
Andi Dewi Riang Tati ${ }^{1}$, Bahri $^{2}$ \\ \{d3wi1979@gmail.com ${ }^{1}$, bahrisejarah@gmail.com $\left.{ }^{2}\right\}$ \\ ${ }^{1}$ Department of Primary Teacher Education Study Program, the Faculty of Education, State \\ University of Makassar, South Sulawesi, Indonesia \\ ${ }^{2}$ Department of History Education Study Program, State University of Makassar, South \\ Sulawesi, Indonesia
}

\begin{abstract}
This study discusses the influence of classroom management on student motivation in social science subject in fourth grade Telkom Elementary School of Rappocini District of Makassar City. The formulations of the problem in this study are (1) what is the picture of classroom management in Social Science subject in the fourth grade Telkom Elementary school? (2) What is the picture of student learning motivation in Social Science subject in the fourth grade of Telkom Elementary School? (3) Is there an effect of classroom management on student motivation in Social Science subject in fourth grade of Telkom elementary school?. The purposes of this study are (1) To find out the picture of classroom management in Social Science subject in the fourth grade of Telkom elementary school, (2) To find out the description of students' motivation in Social Science subject in the fourth grade of Telkom Elementary School. (3) To determine the effect of classroom management on student motivation in Social Science subject in fourth grade of Telkom elementary school. The approach used in this research is quantitative with the type of preexperiment research design with the pretest, treatment, and posttest stages. The research variables consist of two, namely the independent variable includes classroom management and the dependent variable includes motivation to study Social Science. The study population was all fourth grade students of Telkom Elementary School with 52 students and the sample of this study was fourth grade B students, amounting to 26 students. Data collection techniques used was questionnaires and observations. Data analysis techniques used descriptive statistical analysis and inferential statistical analysis. The results showed that (1) The learning process that lasted for four meetings and was observed using a classroom management observation sheet showed progress and was categorized very effective, (2) Student learning motivation after treatment of classroom management showed improvement. This can be seen from the average results of student learning motivation questionnaires before treatment are in the low category. Meanwhile, after being given treatment the results of the average
\end{abstract}


questionnaire of students' learning motivation were in the very high category, (3) There was a positive influence of classroom management on the motivation of learning of fourth grade students of Telkom of Rappocini District of Makassar City. This is evidenced by the significant differences before and after treatment in which the probability value is smaller than 0.05 . The value of sig (2-tailed) $(0,000)<(0.05)$ then Ho is rejected and $\mathrm{Ha}$ is accepted.

Keywords: class management, social science, learning motivation

\section{INTRODUCTION}

The skill of managing classes is important possessed by every teacher because a teacher plays an important role in the teaching and learning process so that teaching objectives can be achieved. Students in a group may not have homogeneous abilities and characteristics, even though the age of the students is relatively the same. Class management is related to the ability of teachers to create pleasant learning situations and conditions so that learning objectives can be achieved. Class management is not just a neat and comfortable spatial planning. But how the teacher is able to manage the classroom so that the learning process in the classroom is conducive and the teacher is able to instill positive things to students as the goal of the learning process one of which is to educate students to have ethics.

Class management is an effort that is intentionally carried out in order to achieve teaching objectives or classroom management activities for teaching purposes (Rohmah, 2012). So the authors argue that class management should be the task of a teacher to create, improve and maintain class systems or organizations, so students can utilize their abilities, talents and energy on individual tasks. Usman (2013) argues that classroom management is a teacher's skill to create and maintain optimal learning conditions and restore them when disturbances occur in the learning process.

According to Suryana (2012) class management is an effort to manage students in the class conducted to create and maintain classroom conditions / conditions that support the learning program by creating and maintaining student motivation to always get involved and participate in the educational process in school.

Class management aims to create a comfortable atmosphere for the classroom as a place for teaching and learning activities. Thus, these activities will be able to run effectively and directed so that learning objectives that have been set can be achieved for the formation of quality human resources (Wiyani, 2013).

Based on the author's observations carried out during May 2019 in class IV B SD Telkom Makassar, not all students are easy to manage in learning, there are rowdy students, students who often make fun of their friends, students who find it difficult to focus, students who often break the rules, and so on. The atmosphere is not conducive seen when the teaching and learning process takes place. The difficulty of the teacher controlling the teaching and learning activities that occur affects the involvement and enthusiasm of students in following the lesson. The situation occurs because students feel less given attention by the teacher and students feel that one student gets more attention than other students. At the time of learning, students are able to focus their attention in just the first few minutes, then busy alone or talking with other friends. This is also seen when giving assignments by the teacher. Although students have been explained clearly and loudly in front of the class, there are still many 
students who feel the need to go forward one by one to the front of the class asking the teacher for an explanation of the assignment that has just been given.

\section{METHOD}

\section{A. Approach and type of research}

This type of research is a Pre Experiment research with One Group Pretest-Posttest design research design. Researchers used this design to determine the effect of classroom management on students' motivation in grade IV social sciences subjects at SD Telkom Makassar. This study does not use a comparison class but has used an initial test in the form of a questionnaire to determine student motivation so that the influence of classroom management can be known certainty.

\section{B. Variables and research designs}

1. This study has 2 variables, namely:

\section{a. Independent Variable (Independent)}

The independent variable of this research is classroom management. The intended classroom management is a series of activities carried out by the teacher to create a class atmosphere to suit its objectives. The action is manifested in the communication of the relationship between the teacher and students. This activity can be done by physically managing the class and managing the students themselves. Physical classroom management in the form of seating arrangements, placement of class stationery (markers, blackboard eraser, LCD remote control), placement of wall hangings related to learning material, calendars in the right place, and how the teacher arranges lighting and class cleanliness. For student management, that is how the teacher shares the attention of all students, divides the study groups, makes variations in learning, and fosters good relations between the teacher and students and students and students.

\section{b. Dependent Variable}

The dependent variable of this research is learning motivation. Learning motivation in question is internal and external encouragement to students who are learning to make behavioral changes. Learning motivation is a process that encourages learning, direction, and persistence in behavior. That is, motivated behavior is behavior that is full of energy, directed and durable.

\section{Research Design ;}

The research design is the chosen way of conducting research procedures or steps. This experimental research uses the form of One group pretest posttest Design, which is one part of the pre-experiment. In this research design there is only one sample class chosen to be applied in class management. To see the effect of classroom management on student learning motivation, the results of the test before and after the research results are compared. Clearly, research can be seen in the following table: 
Table 3.1 Research Design

\begin{tabular}{c|c|c|c}
\hline $\begin{array}{c}\text { Group } \\
\text { (class) }\end{array}$ & Pre-Test & Treatment & Post-Test \\
\hline Eksperimen & $\mathrm{O}_{1}$ & $\mathrm{X}$ & $\mathrm{O}_{2}$ \\
\hline \multicolumn{4}{c}{ Source: Sugyono (2017) }
\end{tabular}

Information:

$\mathrm{O} 1$ = Pre-Test (Provision of student learning motivation questionnaire before applying classroom management)

$\mathrm{O} 2=$ Post-test (Provision of student learning motivation questionnaire after the implementation of classroom management)

$\mathrm{X}=$ Application (treatment) with class management.

\section{Research Population and Samples}

The population is the entirety of the object under study to study and draw conclusions. The population in this study were all students of class IV SD Telkom Makassar, which amounted to 52 people. The sample technique used is Simple Random Sampling by drawing. All 4 classes consisting of two classes each have 26 students and all members of the population have the same opportunity to become sample objects. The sample of this study was 26 students in class IV B.

Table 3.2 Students grade IV

\begin{tabular}{cc}
\hline women & 10 students \\
\hline men & 16 students \\
\hline Total & 26 students \\
\hline
\end{tabular}

Source: Makassar Telkom Elementary School

\section{Data Collection Techniques and Procedures}

\section{Data Collection Techniques}

The techniques used to obtain data in this study are as follows:

\section{a. Questionnaire (Questionnaire)}

According to Suharsimi Arikunto (2010: 140) "the questionnaire is a number of questions or written statements that are used to obtain information from the respondent in the sense of a report about his personality or things he knows". Furthermore according to Sugiyono (2010: 142) "questionnaire is a data collection technique that is done by giving a set of questions or written statements to respondents to answer".

The questionnaire model used in this study is in the form of a closed questionnaire. The closed questionnaire has provided answer choices so that the respondent only needs to fill in easily and quickly. In this study using a questionnaire in the form of a Likert scale. Likert scale is used to measure attitudes, opinions, perceptions of a person or group of people about social phenomena.

Table 3.3 Alternative Answers for Research Instruments

\begin{tabular}{ccc}
\hline $\begin{array}{c}\text { Alternative } \\
\text { answers }\end{array}$ & \multicolumn{2}{c}{ Score } \\
\hline Always & Positifve(+) & Negative (-) \\
\hline Often & 4 & 1 \\
\hline
\end{tabular}




\begin{tabular}{ccc}
\hline Rarely & 2 & 3 \\
\hline Never & 1 & 4 \\
\hline
\end{tabular}

Source: Sugiyono (2017)

\section{b. Observation Method}

According to Sugiyono (2010: 145) "observation is a data collection technique that has specific characteristics. In observation, the observer is involved in the daily activities of the person being observed or used as a source of research data. " The researcher chose the observation technique because the researcher wanted to see the activities of the teacher in the classroom in managing classroom management and how it affected the students' motivation. In this study the observation guidelines used a Likert scale. The activities observed were preparation, opening, core activities in the form of delivering material with classroom management skills, feedback, and closing. The observed aspects are categorized into the following table:

Table 3.4 Implementation of the Learning Process

\begin{tabular}{ll}
\hline \multicolumn{1}{c}{ Score } & Category \\
\hline$<20 \%$ & Very ineffective \\
\hline $21 \%-40 \%$ & Less effective \\
\hline $41 \%-60 \%$ & Quite effective \\
\hline $61 \%-80 \%$ & Effective \\
\hline $81 \%-100 \%$ & Very effective \\
\hline \multicolumn{3}{r}{ Source : Sugiyono (2017) }
\end{tabular}

\section{c. Documentation}

Documentation is a data collection technique by collecting all documents for purposes such as student questionnaire sheets, pictures of student activities, conditions of the learning environment and other documents from the experimental class.

\section{Data Collection Procedure}

Learning is carried out during 4 meetings. The first meeting as a pretest. The second, third meeting, as treatment (action). The fourth meeting as a posttest. Each meeting is held in $3 \times 35$ minutes. The time used is adjusted to the learning of social sciences in the school concerned. The details of the procedure are as follows:

\section{a. Pretest}

Pretest activities carried out before treatment with the aim of knowing the ability and motivation of students' initial learning before being given action in the experimental class.

\section{b. Provision of Treatment}

Provision of treatment by managing class management carried out in the experimental class.

\section{c. Posttest}

At this stage, students are given a number of questionnaires containing statements made after treatment to determine the effect of applying classroom management to student motivation. 


\section{Test the Validity of Instruments}

The validity test of the instrument used is intended to find out whether the instrument used can reveal data from the variables studied appropriately. The instrument validation that will be used in this research is content validation. Content validation is validation carried out by experts.

\section{E. Data Analysis Techniques}

The data analysis technique used in this study is a quantitative data analysis technique. Data analysis was used to determine student learning outcomes in the cognitive domain about the effects of classroom management on student motivation. Data analysis techniques in quantitative research is to use statistics. The data obtained were analyzed using statistical analysis techniques, namely descriptive statistics and inferential statistics.

\section{Descriptive Statistics Analysis}

Descriptive Statistics Analysis is used to analyze data by describing or describing data that has been collected as it is without intending to make conclusions that are applicable to the public. Based on this opinion, the descriptive statistical analysis in this study is used to describe the level of student motivation in learning Social sciences when treated with the management of classroom management seen from the average value (mean), middle value of data (median), lowest value of data (minimum), highest data value (maximum), and standard deviation (standard deviation).

The criteria for the level of inclination in measuring variable results are determined by the research distribution table created by determining the class of intervals and their categories using the following formula:

Information

$$
\mathrm{i}=\frac{\text { Range }}{\text { Kategori }}
$$

i : Class interval

Range : Highest score - lowest score

Category : According to the desired number of categories

Learning motivation variables are described using categorization. From the results of the values of learning motivation variables, categorized into:

Table 3.5 Categories of Learning Motivation

\begin{tabular}{lll}
\hline No. & Interval & Category \\
\hline 1. & $76-100$ & Ver High \\
\hline 2. & $51-75$ & High \\
\hline 3. & $26-50$ & Low \\
\hline 4. & $1-25$ & Very Low \\
\hline
\end{tabular}

Sumber: Hasil olah data motivasi belajar

\section{Inferential Statistical Analysis}

Inferential statistical analysis is intended to test the research hypothesis, before testing the hypothesis first carried out the assumption test as a prerequisite for hypothesis testing. The tests required are: 


\section{a. Data Normality Test}

Data normality test is carried out to find out data taken from populations that are normally distributed or not. Testing the normality of data in this study using the Kolmogrove-Smirnov Normality Test. Student learning motivation questionnaire data is said to be normally distributed if the significance of the two-sided test results of the calculation is greater than 0.05 .

\section{b. Hypothesis testing}

Paired Sample T-test

To see the difference in the results of the questionnaire before and after the treatment of class management was applied, the data were analyzed using Paired Sample t-Test. Pairedsample t-Test analysis is a procedure used to compare the average of two variables in one group. This means that this analysis is useful for testing one sample that receives a treatment which will then be compared on average from the sample between before and after treatment.

Then to determine the selected hypothesis can be known by first determining the table. For paired-sample t-Test the value of df (degree of freedom) is the number of samples minus one or $\mathrm{n}-1$ for one variable. If $\mathrm{t}>\mathrm{t}$ table then $\mathrm{HO}$ is rejected and $\mathrm{Ha}$ is accepted. In addition, it can also be done by looking at the provisions, namely if sig. $<0.05$ then $\mathrm{Ha}$ is accepted and $\mathrm{H} 0$ is rejected. Whereas if the value of sig. $>0.05$ then $\mathrm{Ha}$ is rejected and $\mathrm{HO}$ is accepted.

\section{RESULT AND DISCUSSION}

\section{A. Result}

\section{Overview of Class Management}

The description of class management in social sciences class IV is obtained through observational activities conducted during $2 \mathrm{x}$ meetings. Class management skills in the experimental class have a positive influence on increasing student motivation. This is evidenced by the results of observations made during the learning process. The following table can be seen the results of the implementation of learning in the experimental class.

Table 4.1 Observation Results of the Implementation of Learning Processes

\begin{tabular}{llcc}
\hline No & $\begin{array}{l}\text { Activity } \\
\text { Observed }\end{array}$ & $\begin{array}{c}\text { Sceting } \\
\mathbf{1}\end{array}$ & $\begin{array}{c}\text { Meeting } \\
\mathbf{2}\end{array}$ \\
\cline { 2 - 4 } 1. & Preparation & 2 & 4 \\
\hline 2. & Opening & 3 & 4 \\
\hline 3. & $\begin{array}{l}\text { Core Activity } \\
\text { (Class } \\
\text { Management } \\
\end{array}$ & 3 & 3 \\
\hline 4. & Fkill) & 3 & 4 \\
\hline 5. & Closing & 4 & 4 \\
\hline Total & & 15 & 19 \\
\hline \multicolumn{2}{l}{ Percetage of Total } & $75 \%$ & $95 \%$ \\
\hline
\end{tabular}




\begin{tabular}{lcc}
\hline Category & Effective & Very \\
Effective
\end{tabular}

Based on table 4.1 it can be concluded that the learning process was effective at the first meeting with a percentage of $75 \%$. The data shows that the delivery of material by implementing classroom management has been effective, but there are still implementation procedures that have not been maximally fulfilled. At meeting 1 namely treatment not yet held preparatory activities get a score of 2 because the teacher has not arranged the student's seat and table. The teacher also has not placed markers, erasers, calendars, and wall hangings related to social sciences learning in the right place and easily accessible to students. The opening activity got a score of 3 because the teacher was able to guide students to open lessons, read prayers, and attendance, but had not made apersepi optimally. The core activity gets a score of 3 because the teacher gives clear instructions when giving math assignments and working on the problems but does not adjust the teaching methods with the learning material. Feedback activities get a score of 3 because the teacher has been able to give appreciation to each student and group but has not given an opportunity to group representatives to present their assignments. The closing activity gets a score of 4 because the teacher succeeds in concluding learning and also gives motivation and moral messages to students at the end of their learning. While at the second meeting after being given treatment the learning process took place very effectively compared to the previous meeting, this was indicated by the implementation of activities at almost every point that had an increase with a percentage of $95 \%$.

This shows an increase in almost every aspect of learning activities, thus the learning process is categorized as very effective.

\section{Description of Student Motivation in Learning Social Sciences}

To see the picture of motivation to study social science students in class IV SD Telkom Makassar, it is necessary to hold a pretest before treatment. The questionnaire that was tested by experts was then distributed to Grade IV students, amounting to 26 students.

In the questionnaire there are items with details: 1) For positive statements regarding student motivation there are 25 statements. From the 25 items of statements there are 2 answers, namely with the following provisions and scores: 2) For items with answers that are very appropriate, appropriate, quite appropriate, and not appropriate and always, often, rarely, and never in sequence with a score of $4,3,2$, and 1 ; The results of the questionnaire are entered into a table to be converted into quantitative data.

\section{a. Student Pretest Data on Learning Motivation of social science}

Determination of students' pretest quantitative scores is to add up the questionnaire answers of respondents according to the frequency of answers. The results of descriptive analysis for the results of student pretest answers relating to the dependent variable namely student learning motivation in social science subjects are presented as follows: 
Table 4.2 Distribution of Results Students Questionnaire Motivation Learning Before Management Classroom Management.

\begin{tabular}{lllllc}
\hline No & Category & $\begin{array}{l}\text { Very } \\
\text { High }\end{array}$ & High & Low & $\begin{array}{c}\text { Very } \\
\text { Low }\end{array}$ \\
\hline 1 & $\begin{array}{l}\text { The desire to } \\
\text { succeed }\end{array}$ & 0 & 4 & 16 & 6 \\
\hline & $\begin{array}{l}\text { Tenacious } \\
\text { faces } \\
\text { difficulties }\end{array}$ & 0 & 7 & 13 & 6 \\
\hline 3 & $\begin{array}{l}\text { There is } \\
\text { encouragemen } \\
\text { t and learning } \\
\text { needs }\end{array}$ & 0 & 20 & 6 \\
\hline 4. & $\begin{array}{l}\text { Do not get } \\
\text { bored quickly } \\
\text { on routine } \\
\text { tasks }\end{array}$ & 0 & 15 & 11 \\
\hline 5. & $\begin{array}{l}\text { Happy to find } \\
\text { and solve } \\
\text { problems }\end{array}$ & 0 & 13 & 13 \\
\hline 6. & $\begin{array}{l}\text { Can defend } \\
\text { his opinion }\end{array}$ & 0 & 0 & 15 & 11 \\
\hline 7. & $\begin{array}{l}\text { There is an } \\
\text { appreciation } \\
\text { for learning }\end{array}$ & 6 & 16 & \\
\hline
\end{tabular}

Table 4.2 shows that the indicators of learning motivation are the desire and desire to succeed in the low category with the acquisition of only 4 students in the high category, 16 students in the low category and 6 students in the very low category. The tenacious indicator faced difficulties in the low category with the acquisition of 7 students in the high category, 13 students in the low category and 6 students in the very low category. On the indicator of the encouragement and needs in learning are in the low category with the acquisition of 20 students in the low category and 6 students in the very low category. In the category of not getting bored with routine tasks in the low category with the acquisition of 15 students in the low category and 11 in the very low category. In the category of happy looking for and solving problems are in the low category with the acquisition of 13 students in the low $\begin{array}{lllll}\text { category and } & 13 & \text { students the }\end{array}$ very low category. The indicators can maintain their opinions in the low category with the acquisition of 15 students in the low category and 11 students in the very low category. The last indicator is the existence of awards in learning in the low category with 6 students in the high category, 16 students in the low category and 4 students in the very low category.

Based on table 4.2 the distribution of the results of student learning motivation questionnaire answers before class management is in the low category. The results of descriptive analysis for the results of students' pretest answers relating to the dependent variable namely student learning motivation in social science subjects are presented as follows: 
Table 4.3 Student Qualification and Pretest Intervals

\begin{tabular}{|c|c|c|c|c|c|}
\hline $\begin{array}{l}\text { Interva } \\
1 \text { Value }\end{array}$ & Averag & $\begin{array}{l}\text { Qua } \\
\text { lifying }\end{array}$ & Catagory & $\begin{array}{l}\text { Feq } \\
\text { uenc } \\
y\end{array}$ & $\begin{array}{l}\text { Cum } \\
\text { uativ } \\
\mathrm{e} \\
\text { Perce } \\
\text { ntage }\end{array}$ \\
\hline 76-100 & \multirow{4}{*}{50,192} & $\begin{array}{l}\text { Very } \\
\text { High } \\
\end{array}$ & \multirow{4}{*}{ Low } & & \\
\hline $51-75$ & & High & & 1: & $50 \%$ \\
\hline $26-50$ & & Low & & 13 & $50 \%$ \\
\hline $1-25$ & & $\begin{array}{l}\text { Very } \\
\text { Low }\end{array}$ & & & \\
\hline
\end{tabular}

The data in table 4.3 above shows that $50 \%$ or 13 students are in the low category and $50 \%$ or 13 students are in the high category. This is based on the average results of student questionnaire answers.

Based on the description it was found that the motivation to learn social science students before being given treatment or treatment at a low level. This is based on the analysis of students' pretest questionnaire answers that on the learning motivation indicator questionnaire there are indicators that are still low. In learning motivation there are several indicators, namely: 1) the existence of a desire and desire to succeed; 2) resilient to face difficulties; 3) there are encouragement and needs in learning; 4) do not get bored quickly on routine tasks; 5) Happy to find and solve problems in problems; 6) Can defend his opinion; 7) There is an appreciation in learning. Student motivation is in the low category because there are indicators that are still lacking based on questionnaire analysis.

\section{a. Student Post-test Data on Learning Motivation in Social Sciences}

As for the results of descriptive analysis for the results of students' posttest answers relating to the dependent variable namely student motivation in social science subjects are presented as follows:

Table 4.4 Distribution of Results Learning Questionnaire Answers Motivation Students After Class Management

\begin{tabular}{llllll}
\hline No & Catagory & $\begin{array}{l}\text { Very } \\
\text { High }\end{array}$ & High & Low & $\begin{array}{l}\text { Very } \\
\text { Low }\end{array}$ \\
\hline 1 & $\begin{array}{l}\text { The desire to } \\
\text { succeed }\end{array}$ & 19 & 7 & 0 & 0 \\
\hline 2 & $\begin{array}{l}\text { Tenacious } \\
\text { faces } \\
\text { difficulties }\end{array}$ & 11 & 15 & 0 & 0 \\
\hline 3 & $\begin{array}{l}\text { There is } \\
\text { encourageme } \\
\text { nt and } \\
\text { learning } \\
\text { needs }\end{array}$ & 13 & 0 & 0 \\
\hline
\end{tabular}




\begin{tabular}{|c|c|c|c|c|c|}
\hline 4. & $\begin{array}{l}\text { Do not get } \\
\text { bored quickly } \\
\text { on routine } \\
\text { tasks }\end{array}$ & 14 & 12 & 0 & 0 \\
\hline 5. & $\begin{array}{l}\text { Happy to find } \\
\text { and solve } \\
\text { problems }\end{array}$ & 16 & 10 & 0 & 0 \\
\hline 6. & $\begin{array}{l}\text { Can defend } \\
\text { his opinion }\end{array}$ & 18 & 8 & 0 & 0 \\
\hline 7. & $\begin{array}{l}\text { There is an } \\
\text { appreciatio } \\
\mathrm{n} \text { for } \\
\text { learning }\end{array}$ & 9 & 17 & 0 & 0 \\
\hline
\end{tabular}

Table 4.4 shows that the indicators of learning motivation that is the desire and desire to succeed is in the very high category with the acquisition of 19 students in the very high category, 7 students are in the high category. The tenacious indicator faced difficulties in the high category with the acquisition of 11 students in the very high category and 15 students in the high category. In the indicators of encouragement and needs in learning are in the very high category with the acquisition of 13 students in the very high category and 13 students in the high category. In the category of not getting bored quickly on routine tasks that are in the very high category with the acquisition of 14 students in the very high category and 12 in the very high category. In the category of happy looking for and solving problems in the problem is in the very high category with the acquisition of 16 students in the very high category and 10 students in the high category. The indicators can maintain their opinions in the very high category with the acquisition of 18 students in the very high category and 8 students in the high category. In the last indicator, there are awards in learning in the high category with 17 students in the high category and 9 students in the very high category.

Based on table 4.4 the distribution of the results of student learning motivation questionnaire after class management is in the very high category. The results of descriptive analysis for the results of students' posttest answers relating to the dependent variable namely student motivations in social science subjects are presented as follows:

Table 4.5 Student Qualifications and Posttest Intervals

\begin{tabular}{|c|c|c|c|c|c|}
\hline $\begin{array}{l}\text { Interva } \\
1 \text { Value }\end{array}$ & Averag & $\begin{array}{l}\text { Qua } \\
\text { lifying }\end{array}$ & Catagory & $\begin{array}{l}\text { Fequenc } \\
\mathrm{y}\end{array}$ & $\begin{array}{l}\text { Cum } \\
\text { uativ } \\
\text { e } \\
\text { Perce } \\
\text { ntage }\end{array}$ \\
\hline 76-100 & \multirow{4}{*}{86,846} & $\begin{array}{l}\text { Very } \\
\text { High }\end{array}$ & \multirow{4}{*}{$\begin{array}{l}\text { Very } \\
\text { High }\end{array}$} & $\begin{array}{ll}2 & \\
6 & 1 \%\end{array}$ & \\
\hline $51-75$ & & High & & & \\
\hline $26-50$ & & Low & & & \\
\hline $1-25$ & & $\begin{array}{l}\text { Very } \\
\text { Low }\end{array}$ & & & \\
\hline
\end{tabular}


The data in table 4.5 above shows that $100 \%$ of students' motivation or learning motivation of 26 students after being given treatment has increased and is in the very high category. This is based on the average results of student questionnaire answers.

\section{The Effect of Classroom Management on Social Science Learning Motivation in Class IV Students of Telkom Elementary School, Rappocini District, Makassar City}

To determine the effect of classroom management on student motivation, inferential statistical analysis is needed. The results of inferential statistical analysis are used to test the research hypothesis with a t test with a significance level of $\alpha=0.05$. Requirements that must be met for hypothesis testing are the data obtained are normally distributed. To find out whether the data obtained were normally distributed, a data normality test was performed.

\section{a. Data Normality Test}

Data normality test is intended to see whether the sample is normally distributed or not. The normality test statistic used is the One Sample Kolmogorov-Smirnov Test using SPSS software. If the significance obtained is $\alpha(0.05)$, it can be said that the data is normally distributed. Conversely, if the data are not normally distributed, the significance level obtained $<\alpha(0.05)$. Based on the results of data processing (attached), the results of the pretest questionnaire answers were 0.200> alpha 0.05, and the results of the posttest questionnaire answers were $0.154>$ alpha 0.05 , it was found that the data were normally distributed. With normal data, the next stage is the hypothesis test stage.

\section{b. Hypothesis testing}

Hypothesis testing of this study was conducted to determine whether there is a significant influence between classroom management on motivation to learn social science in fourth grade students of Telkom Telkom in Rappocini District, Makassar City in 2018/2019. Hypothesis testing is performed using a paired sample t-test with a significance level $\alpha=0.05$ with samples taken from normally distributed populations.

Data for hypothesis testing is processed by Statistical Package for Social Science (SPSS) program analysis using statistical analysis of the t-test of two dependent samples (paired sample t-tests). Decision making on hypothesis testing is done in two ways, namely:

\section{1) Based on Comparison of $t$-counts and t-tables}

Testing this hypothesis is done by comparing between tcount and ttable. If $t$ count $>t$ table then $\mathrm{HO}$ is rejected and $\mathrm{Ha}$ is accepted, and $\mathrm{t}$ count < t table then Ho is accepted and $\mathrm{Ha}$ is rejected, provided that the price of $t$ is the absolute price, so it is not seen positive $(+)$ or negative (-). From the statistical results using SPSS, the value of tcount $\mathrm{N}(26)=28.076$, while the results of the pretest posttest questionnaire answers are 2.064 so that the results of the questionnaire answers for motivation to learn social science students' count $(28,076)>$ ttable $(2,064)$, so that Ho is rejected or Ha be accepted. Based on these results, it can be concluded that there is a significant influence between the application of classroom management to the motivation of learning social science students of class IV SD Telkom, Rappocini District, Makassar City in 2018/2019 school year.

\section{2) Based on Comparison of Probability Data Value}

Hypothesis testing is obtained by comparing the probability value, if sig (2-tailed) $<\alpha=$ (0.05) then Ho is rejected or Ha is accepted and sig (2-tailed) $>\alpha=(0.05)$ then Ho is accepted 
or Ha is rejected. From the statistical results using SPSS the results of student questionnaire answers obtained significance value sig (2-tailed) $(0,000)<(0.05)$ means that Ho is rejected and $\mathrm{Ha}$ is accepted, it can be concluded that there is a significant influence between the implementation of classroom management management on learning motivation Social science fourth grade students of Telkom Elementary School Rappocini District Makassar City in the 2018/2019 school year.

\section{B. Discussion}

This pre-experimental study, researchers conducted research in class IV Telkom Elementary School Rappocini District Makassar City as an experimental class with 26 students consisting of 10 female students and 16 male students. The research design used in this study is the One group pre-test post-test design which only involves one experimental group where the initial test is given in the form of pre-test and at the end of the study is given post-test.

Data collection techniques performed include (1) questionnaire, which is a useful technique for obtaining data on student motivation. The questionnaire presented is closed, so that respondents are only given alternatives to fill in the answers provided. (2) Observation sheet, used to see the effectiveness of classroom management by the teacher in the learning process. (3) Documentation that is getting data from the results of questionnaire motivation to study social science, data from fourth grade students of Telkom Telkom Makassar. In the research data, the questionnaire was obtained after the Expert Test was held which tested the contents of the questionnaire based on the grid by the Interest Expert. After the validation results are obtained, the questionnaire is used for research in class.

There are 7 indicators of learning motivation variables, including: the desire and desire to succeed, resilient to face difficulties, the encouragement and needs in learning, do not get bored quickly on routine tasks, happy to find and solve problems in the problem, can maintain their opinions, the appreciation in learning.

There are 2 data analysis techniques, namely data processing using descriptive statistics and inferential statistics. Descriptive processing to state the frequency distribution of respondents' scores or describe learning motivation before and after treatment. Inferential processing is used to test the hypothesis that has been provided.

This research was conducted by giving treatment in learning by applying classroom management. To determine whether there is an effect of classroom management on student motivation in social science subjects through pretest and post-test given before and after treatment, which is then analyzed using calculations with the help of the SPSS program.

Based on statistical results using SPSS obtained tcount $=28.076$ while the results of the pretest posttest questionnaire answers were 2.064 so that the results of the questionnaire answers for motivation to study social science students titung (28.076)> ttable (2.064), so that Ho was rejected or Ha accepted. Based on these results, it can be concluded that there is a significant influence between the application of classroom management to the motivation to learn social science class IV students of Telkom Telkom in the Rappocini District of Makassar City in the academic year 2018/2019.

Usman (2013) argues that classroom management is a teacher's skill to create and maintain optimal learning conditions and restore them when disturbances occur in the learning process. In line with this, Rusydie (2011) states that classroom management is all the efforts made to create an atmosphere of effective and enjoyable teaching and learning, and can motivate students to learn well according to their abilities. Thus classroom management that is done 
actively and effectively is able to provide good motivation to students so that the learning process also increases and produces satisfactory grades.

In descriptive data analysis found motivation to learn social science before being given treatment is $50 \%$ or 13 students are in the low category and $50 \%$ or 13 other students are in the high category. This is based on the average results of student questionnaire answers. Based on the description it was found that the motivation to learn social science students before being given treatment or treatment in a low level. This is based on the analysis of students' pretest questionnaire answers that on the learning motivation indicator questionnaire there are indicators that are still low. Furthermore, after treatment was given, it showed that $100 \%$ of students' learning motivation or learning motivation of 26 students after being given treatment had increased and were in the very high category. This is based on the average results of student questionnaire answers.

In the analysis of inferential data consisting of pretest and posttest normality tests of students' learning motivation with the Kolmogorov-Smirnov test results obtained were 0.200 and 0.154 , which means greater than the value of $\alpha=0.05$ so it was found that the pre-test and post-test questions were normally distributed .

The results of the descriptive statistical analysis only involved or showed the value of the pretest and posttest given to only one experimental class, namely class IV Telkom Telkom, Rappocini District, Makassar City, which was given the treatment of classroom management management and not to test hypotheses (provisional estimates that must still be tested for truth) because it has entered the area of inferential statistics. This means that descriptive statistics attempt to describe and analyze a given group without making or drawing conclusions about a larger population or group. Inferential statistics related to decision making. Inferential statistics are based on descriptive statistics.

Based on the results of hypothesis testing with inferential statistics shows the influence of classroom management on learning motivation in fourth grade students of Telkom Elementary School in Rappocini District, Makassar City. Decision making on hypothesis testing is done in two ways, namely comparing ttable and tcount and comparing probability values. From the statistical results using manual calculations for the t-test of two dependent samples (paired sample t-test) combined with the SPSS program, the ttable value for $\mathrm{N}(26)=2.064$ while the $\mathrm{t}$-test results of the student questionnaire answers 28,076 , $\mathrm{t}$-count $(28,076)>\mathrm{t}$-table ( $\mathrm{t}$-table ( $2,064)$ so that $\mathrm{Ho}$ is rejected and $\mathrm{Ha}$ is accepted. Whereas by comparing the probability values, the significance value obtained from the results of the questionnaire pretest and posttest sig (2-tailed) $0,000<\alpha(0.05)$, means that Ho is rejected and Ha is accepted. So there is a significant influence between the effect of classroom management on motivation to learn social science in fourth grade students of Telkom Telkom, Rappocini District, Makassar City.

Class management is all the efforts made to create an atmosphere of effective and enjoyable teaching and learning, and can motivate students to learn well according to their abilities. Therefore, a teacher must be able to create a learning atmosphere and a supportive learning environment for students to increase their motivation to learn. The effort is realized by actions on communication, the relationship between teachers and students to planning teaching preparation.

Class management can also be interpreted in an activity that provides and uses class facilities so that the activity can run effectively. The teacher as the class manager is a person who has a strategic role, that is, those who plan activities to be carried out in class, people who will implement activities planned with students' subjects and objects, people who determine and make decisions with strategies that will be used with various classroom activities, and the 
teacher will also determine alternative solutions to overcome obstacles and challenges that arise.

The teacher in doing teaching assignments in class, needs to plan and determine how the class management needs to be done by paying attention to the conditions of student learning ability and subject matter that will be taught in the class. Develop strategies to anticipate if obstacles and challenges arise so that the teaching and learning process can still run and the specified learning objectives can be achieved.

Class management is the creation of more conducive student learning conditions (Suryana, 2012). While conducive learning conditions are the most important prerequisite for the smooth implementation of student learning activities, so that the smooth learning process influences learning outcomes more optimally. Good class management is one that can serve and help students' needs in learning. Therefore, the characteristics and needs of students are the first things that need to be known and taken into account by the teacher.

\section{CONCLUSSIONS}

Based on the research results described in the previous chapter, it can be concluded as follows:

a. The learning process that lasts for four meetings and is observed using a classroom management observation sheet, the results obtained indicate the progress of improvement and are categorized very effective.

b. Student learning motivation after treatment management of classroom management showed an increase in learning motivation. This can be seen from the average results of student learning motivation questionnaires before treatment are in the low category. Meanwhile, after being given treatment the results of the average student learning motivation questionnaire were in the very high category.

c. There is a positive influence of classroom management on the motivation of students in class IV SD Telkom, Rappocini District, Makassar City. This is evidenced by the significant differences before and after treatment. This is because the probability value is smaller than 0.05 . The value of sig (2-tailed) $(0,000)<(0.05)$ then Ho is rejected and $\mathrm{Ha}$ is accepted.

\section{REFFERENCES}

[1] A.M, Sardiman. 2009. Interaksi dan Motivasi Belajar Mengajar. Jakarta: PT. Rajawali Pers.

[2] Aqib, Zainal. 2010. Penelitian Tindakan Kelas. Bandung: Yrama Widya.

[3] Arikunto, S. 2010. Prosedur Penelitian Suatu Pendekatan Praktik. Jakarta: Rineka Cipta.

[4] Djamarah, Syaiful Bahri dan Zain, Aswan. 2010. Strategi Belajar Mengajar. Jakarta: Rineka Cipta.

[5] Fitri, Rahma. 2014. Penerapan Strategi The Firing Line Pada pembelajaran Ilmu pengetahuan sosial Siswa Kelas XI IPS SM Negeri 1 Batipuh. Jurnal Pendidikan Ilmu pengetahuan sosial, Vol. 3 (1): 18-22.

[6] Hamdani. 2011. Strategi Belajar Mengajar. Bandung: Pustaka Setia.

[7] Jucius, Michael. 2012. Personnel Management. Illinois: Richard D Iswin Inc.

[8] Karwati, Euis dkk. 2014. Manajemen Kelas. Bandung: Alfabeta. 
[9] Kasmadi \& Sunariah. 2014. Panduan Modern Penelitian Kuantitatif. Bandung: Alfabeta.

[10] Khodijah, Nyayu. 2014. Psikologi Pendidikan. Jakarta: Rajawali Pers.

[11] Kumara, Amitya. 2012. Program Menciptakan Kelas Bersahabat dan Pengelolaan Kelas. Jurnal Intervensi Psikologi, Vol. 4 (2): 194.

[12] Maulidah, Idah. 2017. Hubungan Kemampuan Guru Mengelola Kelas dengan Motivasi Belajar Siswa di SMK Citra Nusantara Panongan Kabupaten Tangerang Tahun Ajaran 2016/2017. Skripsi. Tangerang: Universitas Islam Negeri Syarif Hidayatullah.

[13] Muhaimin. 2002. Paradigma Pendidikan Agama Islam. Bandung: Remaja Rosyda Karya.

[14] Puspita, Dewi Ria. 2017. Hubungan Keterampilan Guru Mengelola Kelas dengan Motivasi Belajar Siswa di Madrasah

[15] Ibtidaiyah Hijriyah II Palembang. Skripsi. Palembang: UIN Raden Fatah Palembang.

[16] Rohmah, Noer. 2012. Psikologi Pendidikan. Yogyakarta: Teras.

[17] Rubiyanto, Rubino. 2013. Metode Penelitian Pendidikan. Surakarta: Universitas Muhammadiyah Surakarta.

[18] Rusydie, Salman. 2011. Prinsip-Prinsip Manajemen Kelas. Jogjakarta: DIVApress.

[19] Saud, Udin Syaefudin. 2013. Pengembangan Profesi Guru. Bandung: Alfabeta.

[20] Sudijono, Anas. 2013. Pengantar Evaluasi pendidikan. Jakarta: PT. Raja Grafindo Persada.

[21] Sugiyono. 2016. Metode Penelitian Kuantitatif Kualitataif dan Kombinasi. Bandung: Alfabeta.

[22] Sugiyono. 2010. Metode Penelitian Pendidikan Pendekatan Kuantitatif, kualitatif, dan $R \& D$. Bandung: Alfabeta.

[23] Sulastri, Lilis. 2014. Manajemen Sebuah Pengantar Sejarah, Tokoh, Teori, dan Praktik. Bandung: La Goods Publishing.

[24] Suprijono, Agus. 2010. Cooperative Leraning Teori dan Aplikasi PAIKEM. Yogyakarta: Pustaka Pelajar.

[25] Suryana, Edeng. 2012. Manajemen Kelas Berkarakteristik Siswa. Jurnal Pendidikan Islam, Vol. 1 (2): 1.

[26] Uno, Hamzah B. 2010. Teori Motivasi dan Pengukurannya. Jakarta: PT Bumi Aksara.

[27] Usman, Moh. Uzer. 2013. Menjadi Guru Profesional. Bandung: Remaja Rosdakarya.

[28] Wahyuni, Esa Nur. 2009. Motivasi dalam Pembelajaran. Malang: UIN Malang Press.

[29] Winarsunu, Tulus. 2010. Statistik dalam Penelitian Psikologi dan Pendidikan. Malang: UMM Press.

[30] Wiyani, Ardi Novan. 2013. Manajemen Kelas. Yogjakarta: Ar-Ruzz Media 